[Codd, J., \& Sullivan, K. (1997). Quality Assurance and Audit in New Zealand Universities: A Review and Case Study. New Zealand Annual Review of Education, 6, 29-50]

\section{Quality Assurance and Audit in New Zealand Universities: A Review and Case Study}

\author{
JOHN CODD AND KEITH SULLIVAN
}

\section{Abstract:}

Along with other institutions of higher education, the New Zealand universities are responding to pressures for increased accountability by developing policies and procedures for the maintenance of quality assurance and control. This paper reviews these developments, with a particular focus on the role of the New Zealand Universities Academic Audit Unit (AAU). In the period February to August 1996, the first full academic audit was undertaken by the AAU at Victoria University of Wellington (VUW). Taking this as a case study, the paper examines some of the issues surrounding quality assurance and audit in higher education and presents a critical review of current directions.

T

he New Zealand university system has strong historical links with the British universities. It is not surprising, therefore, that societal pressures for increased accountability have given rise to similar policy responses. The establishment of an Academic Audit Unit is a prime example of such a response. The British AAU was established in 1990 by the Committee of Vice-Chancellors and Principals. In 1992 its Director, Peter Williams, visited New Zealand to participate in the first of three seminars on quality assurance conducted that year by the New Zealand Vice-Chancellors' Committee (NZVCC) with assistance from the University Teaching Development Centre (UTDC) of Victoria University. Cedric Hall (1992) has provided an account of these seminars leading up to the decision by the NZVCC early in 1993 to establish an AAU for New Zealand's universities.
The AAU was established on 1 February 1994 with a Board appointed by the NZVCC, a secretariat (headed by a Director, Dr David Woodhouse) and a register of auditors. The main functions of the Unit as defined in its terms of reference are to:

i. consider and review the universities' mechanisms for monitoring and enhancing the academic quality and standards which are necessary for achieving their stated aims and objectives;

ii. comment on the extent to which procedures in place in individual universities are applied effectively;

iii. comment on the extent to which procedures in place in individual universities reflect good practice in maintaining quality; and

iv. identify and commend to universities good practice in regard to the maintenance and enhancement of academic standards at national level. (Woodhouse, 1995, p. 1)

During 1994-5 the AAU completed the task of selecting and training auditors and carried out pilot audits of the University of Auckland and Lincoln University. In 1996, the Unit undertook full audits of Victoria University, Otago University and Canterbury University, producing an Academic Audit Report in each case. Audit is thus now an established feature of the New Zealand university system.

\section{The Background}

As a result of the reforms of educational administration of the late 1980s (Picot, 1988; Hawke, 1988; Learning for Life 1 and 2, 1989), the scene was set for extensive change in the university sector. A major theme of the reforms was accountability, and for the universities this was legislated for in both the Public Finance Act (1989) and the Education Amendment Act (1990). As a consequence, the universities are now required to provide government with both a statement of objectives (a charter of goals and purposes) and a service performance statement in relation to these objectives.

Further to this, Rawlings (1995) notes that internal pressures have come both from the community and the universities for increased accountability and for greater transparency of structures and processes. In a climate of globalisation, international pressures also play an important role in bringing to the fore prevalent international ideologies and notably, in this case, the move towards international benchmarking of universities and their programmes: 
(i) a philosophy of accountability promulgated by many governments, most noticeably by the Conservative Government in England;

(ii) a need for international standards (p. 4).

Barnett (1994) argues that the traditional role of the university is no longer tenable within the changing dynamics of the inter-relationship between society, knowledge and higher education. Thus:

Prior to the emergence of the knowledge-based society, the production and dissemination of knowledge was a small-scale affair and society could comfortably leave it to a limited number of institutions (universities) which were granted privileges and autonomies and basically left to get on with things. (Barnett, 1994, p. 21)

Traditionally, the universities were on the periphery of society and although they had important functions in the production of scientific knowledge and "high" culture, these functions were not of immediate interest to the majority in society. Thus, the universities could largely control what counted as "high-level" knowledge and the wider society showed little concern with what went on within their "ivory towers".

This has now changed within the post-modern knowledge-based society. To some extent, the relationships have been reversed. Traditionally, the trend was one in which knowledge gradually travelled, so to speak, from higher education out into society. Currently, the reverse trend seems to be occurring. Society is forming its own definitions of knowledge and these are changing the nature of higher education. New fields of knowledge and the institutions of higher education have a larger more central place within the wider society.

In New Zealand, since the mid-1980s we have witnessed a major transformation of society that began with a reshaping and transformation of the state. This transformation has been described, interpreted and labelled in a variety of ways but its theoretical underpinnings have been most clearly identified by Boston as deriving from four major sources: public choice theory, agency theory, transaction-cost analysis and managerialism (or the New Public Management). The influence of these theories has been extremely pervasive throughout all areas of public policy. Boston argues that:

As a result, the policy agenda has been dominated in recent years by issues relating to the design of incentive structures and contracts, the analysis of alternative governance structures, the avoidance of interest-group capture and bureaucratic capture, the pursuit of contestability and external contracting, the application of agent-principal models to a variety of relationships, the minimization of transaction costs and agency costs, and the specification of outputs and outcomes. (Boston, 1991, p. 23)

It is against this background of governmental policy that New Zealand's universities have responded to political demands for quality assurance and accountability.

\section{Quality Assessment and Quality Audit}

Since the mid-1980s, quality has become a dominant policy issue in higher education throughout the OECD countries. Significantly, the emergence of this concept in the policy discourse coincided with a shift of emphasis from inputs to outputs. In this context, as Marginson (1993, p. 99) suggests, "quality was understood as that which is specifically'not quantity', as improvement without resources". Somewhat ironically, however, quality is generally measured by quantitative indicators such as graduation rates, examination passes, numbers of research publications or the cumulative amounts of research grants. Not only has this generated confusion as to what is meant by quality in higher education but the confusion itself has masked the emergence of stronger forms of bureaucratic control. Thus, as Marginson argues:

This approach to policy on quality provides governments with an open-ended way of bringing pressure to bear on educational institutions for improved performance, perhaps through the intensification or reorganisation of work. In this context quality is an effective tool of control. (Marginson, 1993, p. 99)

In the discourse, quality control (QC) is distinguished from quality assurance (QA), although both refer to procedures and policies that are internal to an institution. In tertiary education institutions QC refers to all the procedures, monitoring activities and instruments by which specified standards are maintained. QC involves checks and measurements on performance in relation to defined indicators such as examination results, pass rates, research outputs etc. QA, on the other hand, refers to all the procedures by which the quality of teaching and research is maintained or improved. 
In a different way, the issue of control is also central to the distinction between quality assessment and quality audit. The former is always undertaken by an external agency, whereas the latter can be carried out either by an internal or external body provided the body has a degree of independence from the people who are responsible for the maintenance of quality within the institution.

Quality assessment is used in Dutch universities and is a traditional inspectorate-type approach. The British White Paper on Higher Education describes it as "an external review of, and judgement about, the quality of teaching and learning institutions" (Higher Education: A New Framework, 1991, p. 24). In this approach, a team of inspectors, in effect, examines the institution's programmes, performance and standards against a standardised set of criteria (bench-marks), draws conclusions and makes recommendations. Judgements are external and internal participation is minimal. The Higher Education Funding Councils in the United Kingdom have adopted this approach and even go so far as to assign grades to the quality of departments or institutions. The main purpose of this kind of quality assessment is to monitor and report upon the specific quality control measurements of an institution or department and to compare these with other similar institutions or departments.

Quality audit, on the other hand, is concerned with examining and making judgements about the quality assurance processes and quality control procedures that the institution has in place. The first step in a quality audit process is that the institution is required to go through a self-review process, so that it can examine its quality assurance processes, become aware of deficiencies and make appropriate adjustments. It is felt that this approach encourages self-reflection and honest critiquing rather than a defensive stance against what can be seen as outside interference. It also encourages ownership of both the processes and the findings. Hall makes the following distinctions:

Academic audit leaves universities to check their own performance - the audit process focuses on whether suitable systems exist for doing this - but quality assessment involves visits by an external panel ... who make assessments of the quality of the teaching in a particular subject across universities. (Hall, 1992, p. 279)

When the NZVCC decided to establish an AAU in 1992, the preferred model was clearly based on quality audit rather than quality assessment.
After discussing, debating and exploring the issues, the NZVCC decided to create what they felt was an appropriate system rather than having one imposed on them as, for instance, was the case for the compulsory sector when the Education Review Office (ERO) was established:

The NZVCC considered how such a mechanism could be established in New Zealand and concluded a separate independent body was the best approach. Such a move would head off any Government attempt to impose their system [emphasis added]. (NZVCC Newsletter, June 1994, No. 31, p. 7)

The NZVCC chose to adopt the quality audit model which the New Zealand AAU describes as:

... a review of the quality assurance processes and quality control procedures of an institution, and includes a sampling process to see if they are working. It may be carried out by an internal or external body, but the body must be independent of the procedures and those responsible for them. A quality audit system betokens a greater trust in the institution than if there is an external quality assessment body. (Woodhouse, 1995, chapter 2, p. 3)

In the UK the Academic Audit Unit was relocated in 1992 under the structure of the Higher Education Quality Council and the process was re-named Quality Audit. The Council is funded by subscriptions from individual universities and colleges of higher education. The services it provides cover:

- quality assurance, including the regular auditing of the ways in which institutions discharge their responsibilities for standards and quality;

- quality enhancement, including the dissemination of good practice;

- acting as a national voice on quality issues in higher education. (Higher Education Quality Council, 1995, Preface)

So far the New Zealand AAU has been mainly concerned with the first of these functions. Its central purpose is:

... to assist each university to achieve an organisational culture that values quality, and is committed to continual enhancement of quality. (Woodhouse, 1995, p. 1) 
Although the process involves "independent public affirmation", it also endeavours to keep the ownership of the process with the university that is being audited. Thus, each university is expected to conduct a self-audit and to submit a report (portfolio) of this self-audit approximately three months before the audit visit. By the time of the visit, the university will have identified key issues and may have already addressed some of the gaps and short-comings in its policies and procedures. From the outset, it was decided that all seven universities would be audited once every four years and that "the reports would be frank but not overtly critical" (Woodhouse, cited in Rawlings, 1995, p. 7).

\section{The VUW Audit}

In 1995, Victoria University of Wellington (VUW) invited the AAU to carry out an audit of its academic quality assurance procedures, thereby becoming the first New Zealand university to be fully audited.

\section{Preparations for the Audit}

As a preparation for the audit, VUW commissioned an external audit in 1994. The University also appointed a special unit to prepare for academic audit by going through an initial self-audit and by the production of a five-part audit portfolio (plus a box of supplementary material).

In the context of wider educational reform, the issue of quality has become central to the many changes that have occurred at VUW over the last eight years. The intention of the University is to address the issue of quality in all spheres, and directly in relation to its underlying principles as expressed in the University Charter. Within the Charter, there is a mission statement that provides the foundations of the University's purpose, and specific principles and practice are formulated from this starting point. The VUW Mission Statement consists of three declarations, the first of which specifically addresses the issue of quality:

Victoria University of Wellington will be a leading, innovative and internationally recognised provider of high quality education.

Victoria University will attract and support a community of staff and students by providing a stimulating environment for teaching, learning and research.
Victoria University will derive its distinctive strength and focus from its location in New Zealand's capital city and the unique resources that it affords. (VUW, 1995b, p. 3)

In turning this statement into policy, the University Charter sets out 10 goals for the 1996-2000 period, one of which again specifically is identified with quality and is stated as follows:

Victoria University will ensure that its teaching programmes, research, services to students, and administration will attain standards which accord with national and international best practice.

In one of the components of the University's audit portfolio, Quality Assurance Provisions - Academic Related (1996b), the University identified eight areas of quality assurance on which it has focused. They are:

- management structure and quality systems

- human resources

- approval and delivery of courses of study

- staff and student research

- review and feedback provisions

- inter-institutional programmes

- $\quad$ support for students

- facilities and related provisions.

More specifically, 15 developments are identified as deserving of special mention, "either because of their innovative features or because of their particular impact upon the University's activities" (VUW, 1996c, p. 10). They are:

- the system of course and teaching evaluations introduced in 1988 which has continued to develop through a consultative process with academic staff to ensure their acceptance;

- the system of departmental and administrative reviews;

- the class representative system organised by the Victoria University of Wellington Students Association (VUWSA) which complements the teaching evaluations of the UTDC by providing immediate information to the departments and course organisers about difficulties when they arise;

- the system of faculty-based workloads and assessment committees which have evolved into major quality assurance and monitoring groups at the faculty level; 
- teaching development provisions offered through UTDC, in particular its course design, small group teaching, research supervision and educational technology support;

- the process developed for handling student grievances;

- the introduction of a statute on conduct and a grievance resolution service;

- the operation of Student Services with its close attention to the monitoring of students' needs and the variety of structures for providing academic advice and support to students;

- the debriefing exercises used by the University in respect of major operational events such as enrolment and the promotions exercise;

- the provision of examination scripts to be completed in te reo Maori;

- the trial process established for the recognition of prior learning in the School of Maori Studies;

- the system for the management of honours and masters courses of study which encourages flexibility and freedom in the design of programmes but which incorporates the University and CUAP approval checks and external scrutiny through (normally) the appointment of external assessors;

- the Treaty of Waitangi Consultative Committee and the development of an operational plan in time for the 1996 budget process;

- the restructuring of the management of postgraduate research with increased emphasis on the student-supervisor relationship and the provision of a thesis management programme for postgraduate students; and

- the development of ethical guidelines and associated monitoring procedures to govern research involving human and animal subjects. (VUW, 1996c, pp. 10-11)

In presenting this list, the University stated that it intended to develop a regime based on an annual operational plan derived from the Charter and linked to the various budget centres (departments, faculties, committees):

There remains a significant amount of detailed planning to link the various operational plans back to the mission and goals statement and to incorporate existing and developing management systems. (p. 10)
It also intended continuous re-evaluation for further improvement:

For example, although the provision of course and teaching evaluations has provided useful feedback to the University and the departments on the quality of education being provided, it still needs to be continuously monitored to ensure that it meets the requirements of a changing educational environment. For this reason, the University's system for evaluating its course offerings and obtaining feedback from various sources is to be reviewed later in 1996. (p. 11)

The final comment in the Report on Quality Assurance at Victoria University of Wellington 1996 states:

... the University views the process of academic audit as an aid to the continuous improvement of its quality assurance provision and systems. The progressive review of systems that has taken place since the decision of the NZVCC to establish an Academic Audit Unit testifies to Victoria University's commitment to continuous improvement.... The principal challenge facing the University is to prepare and implement operational plans based on its mission and goals statement. This process should enable the University's quality assurance systems to be further strengthened and, it is hoped, will introduce the law of parsimony into the University's activities by identifying the simplest and most effective combination of provisions to ensure that the University continues to be a leading, innovative and internationally recognised provider of high quality university education. (VUW, 1996c, p. 21)

VUW's preparations for external academic audit were long, detailed, thorough and productive. For some years in any case, it had been explicitly examining its academic quality assurance procedures, and thus the audit took place in an environment of self-correction and examination. This context may well have supported the audit procedure.

\section{The Audit Visit}

The portfolio provided the basic information for the AAU to prepare for the audit. Subsequently, a review panel of six people visited VUW over a three-day period in March 1996 and interviewed over 230 people including senior and middle managers, academic staff, general staff, 
students, employers and graduates. The AAU states that as it is impossible to cover every aspect of the university, sampling is necessary. The panel selected specific operational sequences (trails); and issues (slices) for discussion with a range of people. This permitted a widely-sampled investigation, and provided the basis for extensive consultation within VUW (p. 1).

\section{The Academic Audit Report}

The AAU prepared its report and sent it to the University for correction of any factual errors. The final report was released in July 1996. In introducing the report, it is stated that the panel members considered their findings in terms of the University's objectives as stated in its charter and mission statement, Towards Our Century - Challenge, Choice, Change: Mission and Goals 1996-2000, and also with reference to the character of the universities as required by the Education Amendment Act, 1990. The report focuses on 12 themes:

1. The Institutional Context: Structure and Planning

2. The Institutional Context: the Quality Management System

3. The Treaty of Waitangi

4. Staff Matters

5. Courses and Programmes

6. Teaching, Learning and Assessment, \& Research and Training

8. Reviews

9. Feedback Processes

10. Joint Franchised and External Programmes

11. Support for Students

12. Facilities and Resources.

However, in the introduction and overview the report highlights five major areas from amongst these: mission and planning; reviews; Treaty of Waitangi; teaching, learning and assessment; and research policy and postgraduate research. Before discussing these, the report implies that any faults are systemic and fixable; it applauds the efforts of staff and students both in terms of their preparation for the audit and in relation to their dedication as professionals or participants:

The panel was impressed by the energy and enthusiasm of the staff and students that it met, and by the high level of commitment of the staff to their teaching and research activities. (AAU, 1996, p. 1)
The next section provides a brief overview of the findings of the audit report and then focuses on the area where the University received the most positive response teaching, learning and assessment.

\section{Overview}

Mission and planning: The audit panel was supportive of the statements contained in the University's Charter and Mission and Goals, but found the linkage between the processes or procedures at the institutional level and their implementation and monitoring at departmental level to be deficient in some respects. It conceded that changes are still under way, but also sensed that the ownership of mission and goals at the upper management levels did not extend to the majority of university staff. It referred to the complexity of management structures and made reference to a student's description of the University as having Byzantine structures.

Reviews: The panel was very supportive of the seven-year cycle of departmental review processes (over 60 took place in the 1990-96 period), especially as it seemed to have so much support from staff in terms of its potential for change and improvement. However, it found the University's planning and implementation processes deficient in that there were difficulties in providing planning direction: "implementation following reviews is not always coherent, systematic or thorough" (p. 2)

Treaty of Waitangi: The panel found that there was an impressive statement of policy about VUW's responsibilities and actions in relation to the Treaty but that, as with other criticisms, planning, timelines and implementation details were lacking. There was also a sense that there was too much reliance on Maori Department staff and an expectation that Maori students and staff should take the initiative; as with the Mission Statement and the Charter, there was a lack of knowledge or ownership generally throughout the University.

Research policy and postgraduate research: The panel reported that despite areas of research excellence, the University suffered through the lack of a comprehensive policy or strategic research plan. It talked of faculties taking initiatives and the Planning and Research Committee making decisions without an institutional framework. It also suggested that staff workloads needed to be differentiated to take account both of research activity and the ability to gain external funding. It also commented on 
evidence of variable practice and postgraduate dissatisfaction, and noted that an institutional policy statement and facilities for postgraduate students had only recently been developed.

\section{Teaching, Learning and Assessment}

In its discussions of teaching, learning and assessment, however, the panel was much more positive, although it also had some criticisms to make. The report states that:

There is clearly a good culture in this area of VUW's activity, and the panel noted many positive features. The University Teaching Development Centre (UTDC) makes a strong contribution in several ways, and there is a good system of student evaluation of teaching and courses that appear to be well accepted by staff. (p. 17)

This section of the audit report deals with:

i. teaching and learning, specifically teaching quality evaluation, class representatives and colleague evaluation of teaching;

ii. workloads and assessment committees dealing with course outlines, assessment and examination statistics;

iii. external assessors.

The following is a summary of the main points:

Teaching and Learning: In terms of teaching and learning, the report "strongly commended" the University's system of peer evaluation, as this supplements student evaluations and allows authoritative comment in a way that student evaluations cannot. In terms of student evaluations, the audit panel expressed the criticism that "despite providing feedback on inadequacies of teaching, students see the deficiencies persisting" (p. 17). However, the report also pointed out that ongoing poor performance is picked up and dealt with, but that the consequences are not necessarily apparent. The report recommended that "It would be helpful if some way could be found of ensuring that the occurrence of positive action is made more widely known" (p. 18).

Class representatives: In terms of class representatives, the report stated that "This representative system is intended to complement the UTDC evaluations and tuition, as it can respond quickly and deal with the ongoing day to day problems. The representative system is 'good as a safety net' as one student put it, but seems to be working only in a very fragmented fashion". It was reported that "VUWSA hopes to have a meeting of all the representatives in each department with the chairperson at the end of each semester, but this will depend on the individual chairperson" (p. 18).

\section{Workloads and Assessment Committees (WACs)}

The report suggests that in relation to assessment and grading, institutional ownership is lacking and that there is "the lack of an overall assessment plan [which] may be responsible for the variability that was observed" (p. 18).

Course outlines: There was positive response from students in relation to course outlines and their logic and the thoroughness of coverage. The report states: "The course outlines and other information given to students is comprehensive. VUW has drawn up a checklist, the WAC compares each course outline with the checklist, and reports back on variations" (p. 19).

Assessment Requirements: There have been several useful approaches in the area of assessment. For instance, marking guides have been developed within the Education Faculty and research has been carried out whereby students have been given marking guides before an assignment and have been asked to mark their own assignments (see Sullivan \& Hall, 1997). The report recommends: "It would be valuable to have grade definitions on a broader scale, and the WACs could have a role in promoting the discussion" (p. 19).

Student workloads: The report states that not all faculties have devised methods for measuring workloads and that the University has convened a committee to review the credit system and to look at issues such as whether a credit is an input or an output.

Examination statistics: The panel found that there was discontinuity in the area of distribution of grades with great variation between departments.

\section{External Assessors}

The University recently formalised its process of using external assessors for Honours and Masters courses. A system has been devised to compile assessors' reports by the Departments and to pass them on to the 
Academic Vice Chancellor who passes them on to the Academic Committee. A report is then compiled and issues are taken up with departments. "The audit panel was able to view this report and found it comprehensive and thorough" (p. 20).

\section{Discussion and Critique}

In his review of the developments leading up to the advent of academic audit in New Zealand universities, Cedric Hall suggested that three change management principles should underpin the reform: (a) academic audit should not generate an increase in the workloads of university staff; (b) the benefits of audit should be transparent to all involved; and (c) there should be acceptance and ownership of the processes by all involved (Hall, 1992, pp. 281-282).

Judging by the way the academic audit was conducted at VUW, it would appear that these principles have indeed been realised.

The AAU worked within their prescribed terms of reference and the process was transparent, open and non-threatening. The audit panel was thorough in its considerations and generous in its comments about the positive aspects of the University. Its report was delivered in a way that was clear and balanced, and the suggestions for improvement that were made were constructive.

Considering the brevity of the visit, the report demonstrates insight and understandings that are both surprising and useful. The authors wish to indicate their support both for an academic audit unit that is controlled by the universities through the NZVCC and its characterisation as a quality audit rather than a quality assessment body. However, in light of potential criticisms and shortcomings, there are several major concerns that need to be addressed.

\section{The Maintenance and Enhancement of Academic Standards}

In concentrating on the auditing of quality assurance, the AAU is focusing on a review of procedures that have been developed in recent years as universities try to find ways to meet accountability demands without compromising university integrity. The development of a set of quality assurance mechanisms and their audit according to a portfolio presented by the universities, as described above, is based largely on trust. In focusing on these procedures and mechanisms rather than on the quality of the university programmes, per se, the universities may be doing themselves a disservice in the long run. Recent developments in
Britain suggest that the terms of reference for academic audit need to be more clearly focused on a full audit of academic standards, rather than the auditing of quality assurance procedures.

In 1995 the British Higher Education Quality Council (HEQC) responded to a challenge from the Secretary of State for Education to place more emphasis on broad comparability in the standards of degrees offered by different institutions. The Chairman of the HEQC, John Stoddart, has stated that the Council responded by setting up the Graduate Standards Programme (a major programme of development work in universities and colleges) and "by giving greater attention within academic quality audit to the ways in which institutions set and monitor their standards" (HEQC, 1995, Foreword). Stoddart suggests that certain broad issues need to be addressed in order to establish comparability between programmes and institutions. Specifically, he asks:

- what should be the nature and purposes of first degrees in UK universities and colleges and how do standards relate to diverse purposes?

- how can reliability and security of degree standards be assured?

- how much comparability between standards/awards across the sector is achievable?

- what is the appropriate balance of responsibility and accountability in the definition and assurance of standards? (HEQC, 1995, Foreword)

These questions are highly pertinent to the New Zealand context also where they have been raised persistently by the New Zealand Qualifications Authority and have provided the raison d'être for proposals to bring all university qualifications onto the National Qualifications Framework. In 1994, the then Minister of Education established a Tertiary Lead Group to work on resolving issues related to the inclusion of all degrees on the Framework. This work was continued in 1995 by the Tertiary Action Group. Also in that year, the NZQA proposed legislation that would replace the NZVCC's statutory responsibility for the approval of university programmes with delegated authority from the NZQA (Codd, 1996, pp. 61-62).

Given this political environment, with its very real threats to the autonomy of the universities, it is perhaps surprising that the academic audit process focuses mainly on procedures and pays little attention to 
standard-setting criteria. The VUW audit was very thorough in its review of quality assurance procedures and developments but was largely silent with regard to the quality of academic programmes per se. The section of the report on teaching and learning discusses the role of UTDC, the quality of student and peer evaluations of teaching, the issue of student representation on committees and academic staff appraisal. All these are arguably useful developments but they do not address the question of whether standards of graduate achievement are being maintained or improved. They seem largely designed to report on whether academic staff are providing suitable products to their customers, the students and potential employers.

A more explicit focus on academic standards would be concerned with the extent to which the university had developed:

(a) explicit and transparent statements of assessment criteria for all course work, research projects, assignments and theses;

(b) clearly defined and documented criteria for different levels of honours;

(c) policies relating to threshold standards, i.e., consistent criteria for determining minimal pass levels of academic performance at crucial assessment points;

(d) stated procedures relating to how and when external assessors/ examiners are to be used, together with documented guidelines and assessment criteria;

(e) policies for moderation of assessments (e.g., sample check-marking of examination scripts, second opinion appraisal of borderline performance).

\section{The Role of the University}

The central feature of most academic courses is their concern with the advancement and criticism of knowledge. Unlike many vocational courses, where the aim is to train in specific skills and competencies, the aim of many university courses is not merely the training of students but their induction into intellectual disciplines and fields of enquiry.

The educational standards appropriate to universities are not standards of consumer demand but standards for the assessment of context-dependent knowledge and professional action. In these circumstances, as Norris argues:
It is not standards of performance that are required since these are beyond our capacity to specify. What is needed are standards of criticism and principles of professional judgement that can inform action in the context of uncertainty and change. (Norris, 1991, p. 337)

These "standards of criticism and principles of professional judgement" reside ultimately within an international academic community. University courses, programmes and qualifications, therefore, should be developed and evaluated against internationally recognised criteria of quality and excellence.

Whereas the VUW audit report is fair in relation to its terms of reference, it does not provide a penetrating critique of the activities of the University. Should it not, in effect, take a step further back and ask the questions, "Is the University effectively doing what a university should do?"; "Is it contributing to developing and disseminating new knowledge?"; "Is it providing an environment where students can develop their thinking capacity or expertise to a high level?"; "Should these questions be the focus of a quality audit rather than concern with the existence of appropriate quality mechanisms?" While there is some mention of the university's role as "critic and conscience of society" (AAU, 1996, p. 7), no attempt is made to evaluate this role in relation to the university that is being audited.

\section{The Relationship between Quality and Resourcing}

It should be self-evident that there is a direct causal link between levels of resourcing and matters of quality. The audit process, however, largely ignores the determining influence of shrinking resources, or the significance of such factors as the gradual increase in student/staff ratios accompanied by increased stress and loss of job satisfaction (Boyd \& Wylie, 1994).

The VUW audit report points out that staff research publications have been dropping off over the past few years, but does not link this to other factors within the university. It could be argued that the gradual increase in student numbers which is not accompanied by a commensurate increase in resources adds to stress and undermines the quality as well as the quantity of research outputs. Inevitably also, in this context, teaching and learning may be impaired.

In comparison with Australia, Britain and the USA, the conditions of service of New Zealand academic staff are poorer. The Report on 
Quality Assurance at Victoria University of Wellington (Victoria University of Wellington, 1996c) points out that New Zealand universities operate at $60 \%$ of Australian university costs and that discrepancies are even greater when compared to the USA and the UK. More specifically, an article entitled "University League Tables 1996" (The Times Higher Education Internet Service, March 1997) showed that a group of British universities of a similar size to VUW had much smaller student:staff ratios. Comparable figures at Warwick, for instance, were 12:1, at Reading 10:1, at Leicester 9:1, and at Liverpool and Glasgow 8:1 (figures relate to the 1993-94 academic year.) The student: staff ratio at VUW in 1995 was 19.1:1 (Victoria University of Wellington, 1996c, p. 7).

\section{The Issue of Independence}

Because the AAU is funded by the NZVCC and is governed by a Board which is appointed by the NZVCC, there is the potential for conflicts of interest and the loss of independence. As with justice, impartiality must not only be done but must be seen to be done.

Each university, in its audit portfolio, to a large extent sets the agenda and supplies the data for the quality audit. The recommendations that are made as a result of the audit are neither binding nor have any timelines for putting them into effect. In addition, the fact that it will be four years before the university will be audited again sets the AAU up to be potentially a "paper tiger". Interest groups and critics could thus claim that the universities have developed a process that in the final analysis "lacks teeth".

\section{Concluding Remarks}

In its wisdom, the NZVCC has opted for a system of quality audit that is under its own control, a system that requires the universities being audited to go through a process of self-reflection, and through the preparation of their audit portfolio allows them to have the opportunity to make their own decisions about what needs to be changed and how to go about doing this. It chose to go down this track because the alternative that was considered, the quality assessment path, meant that control would be surrendered to an external body (such as the NZQA), and there was a risk that the mechanisms would be intrusive and the universities would largely become onlookers in such a process. While in an open democratic society it is of crucial importance that universities maintain their autonomy and preserve their academic freedom, they must also ensure that accountability is more than a transfer of paper, and that procedures for the maintenance and enhancement of quality have real consequences. If they fail in this, UK experience suggests that the audit process may be taken out of the hands of the AAU and vested in another body, which may be quality-assessment rather than qualityaudit driven.

\section{References}

Barnett, R. (1994). The limits of competence. Bucks, UK: Open University Press.

Boston, J., Martin, J., Pallot, J. \& Walsh, P. (Eds.) (1991). Reshaping the State: New Zealand's bureaucratic revolution. Auckland: Oxford University Press.

Boyd, S. \& Wylie, C. (1994). Workloads and stress in New Zealand universities. Wellington: New Zealand Council for Educational Research and Association of University Staff of New Zealand.

Codd, J. A. (1996). Higher education and the Qualifications Framework: A question of standards. Delta, 48(1), 57-66.

Committee of Vice-Chancellors and Principals. (1991). Notes for the guidance of auditors. United Kingdom: CVCP.

Hall, C. (1992a). Quality assurance: Implications for NZ universities from British experience: Report on the NZVCC/UTDC seminar. Wellington: University Teaching Development Centre.

Hall, C. (1992b). Developments in academic audit in New Zealand universities. New Zealand Annual Review of Education, 2, 263-284.

Hawke, G. (1988). Report of the Working Group on Post-Compulsory Education and Training. Wellington: Department of Education.

HMSO. (1991). Higher education: A new framework. London: HMSO.

Higher Education Quality Council. (1995). Graduate Standards Programme: Interim Report. London: Higher Education Quality Council.

Higher Education Quality Council. (1996). Academic standards in the approval, review and classification of degrees. London: Higher Education Quality Council.

Marginson, S. (1993). Education and public policy in Australia. Cambridge: Cambridge University Press.

New Zealand Government. (1989, February). Learning for life: Education and training beyond the age of fifteen. Wellington: Government Print. 
New Zealand Government. (1989, August). Learning for life: Two. Education and training beyond the age of fifteen. Policy decisions. Wellington: Government Print.

New Zealand Universities Academic Audit Unit. (1996). Victoria University of Wellington Academic Audit Report. Wellington: New Zealand Universities Academic Audit Unit.

New Zealand Universities Academic Audit Unit. (1996). Otago University Academic Audit Report. Wellington: New Zealand Universities Academic Audit Unit.

New Zealand Universities Academic Audit Unit. (1995). Audit manual: Second edition. Wellington: New Zealand Universities Academic Audit Unit.

New Zealand Vice Chancellors' Committee. (1992). Report on universities workshop on quality assurance. Quality assurance in New Zealand Universities: Workshop File. Wellington: NZVCC.

NZVCC Newsletter (1994, June), No. 31. Wellington: NZVCC.

Norris, N. (1991). The trouble with competence. Cambridge Journal of Education, 21(3), 331-341.

Rawlings, F. (1995). Academic audit in New Zealand universities: Some considerations. New Zealand Journal of Educational Studies, 30(1), 1-14.

Sullivan, K., \& Hall, C. (1997). Introducing students to self-assessment: Assessment and evaluation in higher education. Journal of Assessment and Evaluation in Higher Education, 22(3) (in press).

Taskforce to Review Education Administration. (1988). Administering for Excellence. (The Picot Report). Wellington: Government Print.

The Times Higher Education Internet Service. (1977, March). University league tables 1996.

Victoria University of Wellington Chairpersons' Handbook. (n.d.) Wellington: Victoria University of Wellington.

Victoria University of Wellington Committees Handbook. (n.d.). Wellington: Victoria University of Wellington.

Victoria University of Wellington. (1995a). The academic structure of the university. Wellington: Victoria University of Wellington.

Victoria University of Wellington. (1995b). Towards our century challenge, choice, change: Mission and goals 1996-2000. Wellington: Victoria University of Wellington.

Victoria University of Wellington. (1996a). Annual report and financial statements for the year ended 31 December 1995. Wellington: Victoria University of Wellington.
Victoria University of Wellington. (1996b). Quality assurance provisions - academic related. Wellington: Victoria University of Wellington.

Victoria University of Wellington. (1996c). Report on quality assurance at Victoria University of Wellington. Wellington: Victoria University of Wellington.

Victoria University of Wellington. (1991). Victoria University of Wellington Charter. Wellington: Victoria University of Wellington.

Woodhouse, D. (1995). Audit Manual: Handbook for institutions and members of audit panels (second edition). Wellington: New Zealand Universities Academic Audit Unit.

\section{The authors}

John Codd is Professor of Policy Studies in Education at Massey University, where he teaches postgraduate courses in educational policy analysis and the theory of educational administration. He has co-edited several books on New Zealand education, and his research on educational reform has been published in international journals. He is currently co-editor of the New Zealand Journal of Educational Studies.

Keith Sullivan is currently a Senior Lecturer and Associate Dean for Postgraduate Studies in the Faculty of Education of Victoria University of Wellington. He has research interests in educational policy and administration in the tertiary sector, in teachers' ideologies and educational reform, in anti-bullying initiatives, and in comparative education. In 1995-96 he was Charter Fellow in Human Rights at Wolfson College, the University of Oxford. 